da institucionalização de um empreendimento privado de ensino superior, bem como os limites e o papel regulador do Estado no ensino superior brasileiro em função da cristalização histórica de um processo de privatização do Estado pelas classes dominantes.

As Instituições Privadas de Ensino Superior, em virtude de seu caráter complementar e acessório do "sistema" público e, acima de tudo, pela sua origem, via de regra, patrimonialista e pela sua total subordinação aos imperativos inerentes a um mercado agonicamente competitivo e dependente de financiamentos e benesses do Estado, têm remota probabilidade de se tornarem universidades.

Palavras-chave: ensino superior, ensino privado, universidade privada.

\title{
Demissão voluntária: passagem da estabilidade para as vulnerabilidades do mundo do trabalho
}

Zilda Vieira de Souza Pfeilsticker

Curso: Doutorado em Sociologia

Data da defesa: 26 de março de 2008

Orientadora: $\operatorname{Prof}^{\mathrm{a}} \operatorname{Dr}^{\mathrm{a}}$ Berlindes Astrid Küchemann

\section{Resumo}

A presente tese é uma reflexão sobre os impactos dos programas de desligamento voluntário (PDV) na vida daqueles que, 
por força das grandes transformações do mundo do trabalho, a eles aderiram e se tornaram conhecidos como pedevistas. Tem como objeto a reinserção dos pedevistas do Banco do Brasil no mercado de trabalho e como objetivo analisar a reinserção desses pedevistas no mercado de trabalho. Parte da premissa de que os funcionários que se desligaram do Banco, seja por pressão, seja voluntariamente, passaram a lidar com a perda do vínculo empregatício como uma mutilação simbólica e ainda são portadores de padrões de uma identidade que os fixa aos paradigmas da estabilidade e da segurança, inadequados aos novos paradigmas da desregulamentação e da flexibilização das relações de trabalho. Para tanto, foi utilizado como recurso metodológico o estudo de caso, dadas as possibilidades que oferece ao aprofundamento da investigação.

A pesquisa confirmou a hipótese de que grande parte dos pedevistas tem encontrado dificuldades de reinserção no mercado de trabalho devido à interferência de seu habitus, que mobiliza suas disposições desenvolvidas sob o paradigma da estabilidade e segurança no emprego. Foi verificado que, ao se desligarem do Banco, os funcionários sentiram que não perderam apenas seu emprego, mas seus projetos de vida, suas referências sociais, econômicas, psicológicas, culturais, simbólicas e, principalmente, a confiança de que detinham o controle de suas vidas. A convivência com a forte cultura organizacional do Banco, que, por quase dois séculos, estabeleceu com seus funcionários o acordo tácito da estabilidade consentida e da lealdade concedida, fez com que eles desenvolvessem elevado grau de pertencimento e identificação com a instituição.

Constatou-se que, após o rompimento com o Banco, os pedevistas passaram a se perceber como deserdados dos ganhos simbólicos associados ao forte estatuto profissional "Banco do Brasil", tendo que reconstruir sua identidade pessoal e sua identidade socialmente reconhecida longe de parceiros, agora tidos como inacessíveis, distantes ou impotentes. Tornaram-se, a partir de então, 
194 Resumos das teses e dissertações apresentadas no PPG-SOL/UnB

personagens da modernidade "líquida", que lhes derrete o "sólido" e os arremessa para as vulnerabilidades do mundo do trabalho.

Palavras-chave: mundo do trabalho, reestruturação produtiva, Banco do Brasil, habitus, identidade, instituição, vulnerabilidade, estabilidade, socialização, cultura organizacional, capital simbólico. 